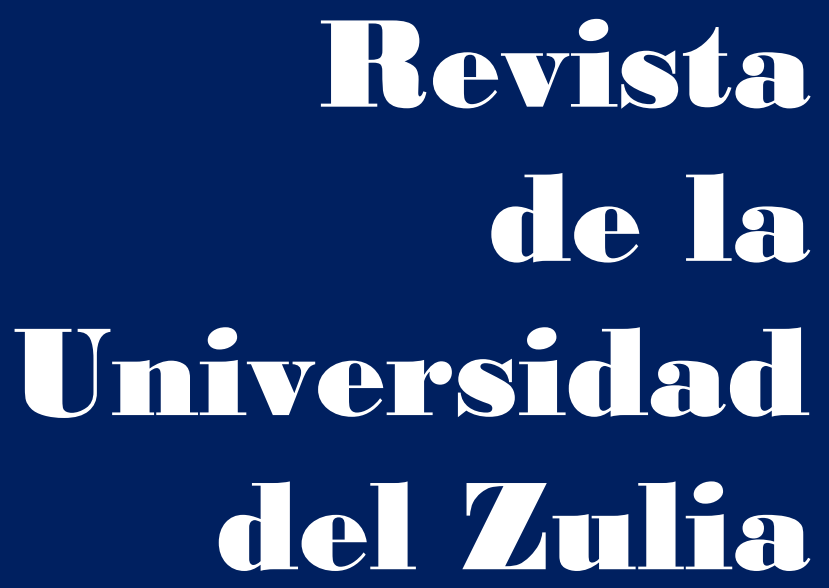

Fundada en 1947

por el Dr. Jesús Enrique Lossada

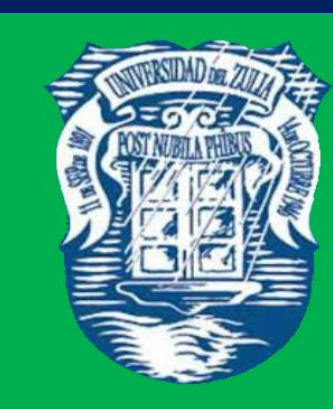

Ciencias del

Agrad,

Ingemiería

y Tecinología

\section{Aกัต 13 No $\mathbf{3 6}$} Enero - Abril 2022

Tercera Épaca

Maracailbo-Venezuela 


\title{
Management accounting and economic security in corporate management of agricultural company operation
}

\author{
Gamlet Y. Ostaev * \\ Rolan A.Alborov ** \\ Dmitry N. Ermakov *** \\ Elena V. Belokurova **** \\ Nikolay V. Artemiev*****
}

ABSTRACT

The article analyzes management accounting and economic security in the corporate governance system of an agricultural organization in an integrated manner, regarding the study of internal and external factors. The objective of the study is to develop an accounting model in business management, taking into account business development and economic security. In accordance with this objective, the main task was determined, to develop a comprehensive mechanism in terms of business development, resource conservation, production, budgeting and economic security. To develop an accounting model in business management, taking into account business development and economic security, the parameterization method was applied by modeling situations under modern conditions. The need to apply a systematic approach is founded, monitoring indicators are proposed to determine the risks and various threats to the operation and development of a business.

KEY WORDS: management; agricultural organization; economic security; integration.

* Candidate of Economic Sciences, Associate Professor of Accounting, Finance and Audit, Izhevsk State Agricultural Academy, 426069, Izhevsk, Studencheskaya Street, 11 Spin-code: 3674-4120. ORCID: https://orcid.org/0000-0003-0869-7378.

** Doctor of Economics, Professor of the Department of Accounting, Finance and Auditing of the Izhevsk State Agricultural Academy, 426069, Izhevsk, Studencheskaya Street, 11 Spin-code: 11106205. ORCID: https://orcid.org/0000-0002-8896-1062.

*** Doctor of Economics, Doctor of Political Science, Professor RUDN University 117198, Moscow, Miklouho-Maclay Street, 6 Spin-code: 6835-3155. ORCID: https://orcid.org/0000-0002-0811-0058.

**** Candidate of Economic Sciences, Associate Professor of the Tyumen Industrial University, a branch in the city of Nizhnevartovsk, 628600, Khanty-Mansi Autonomous district, Nizhnevartovsk, Lenin Street., 2 con.9. Spin-code: 6442-4600. ORCID: https://orcid.org/0000-0003-0809-4446.

***** Doctor of Economics, Associate Professor, Professor of the Department of Administrative Law, Moscow University of the Ministry of Internal Affairs of Russia. V. Ya. Kikotya,117437, Moscow, Academician Volgin Street12, Spin-code: 1055-3115. ORCID: https://orcid.org/0000-0003-0157-4738. 


\section{Contabilidad de gestión y seguridad económica en la gestión corporativa de operación de empresas agropecuarias}

RESUMEN

El artículo analiza la contabilidad de gestión y la seguridad económica en el sistema de gobierno corporativo de una organización agropecuaria de forma integrada, en cuanto al estudio de los factores internos y externos. El objetivo del estudio consiste en desarrollar un modelo de contabilidad en la gestión empresarial, teniendo en cuenta el desarrollo empresarial y la seguridad económica. De acuerdo con este objetivo, se determinó la tarea principal, desarrollar un mecanismo integral en términos de desarrollo comercial, conservación de recursos, producción, presupuestación y seguridad económica. Para desarrollar un modelo de contabilidad en la gestión empresarial, teniendo en cuenta el desarrollo empresarial y la seguridad económica, se aplicó el método de parametrización mediante el modelado de situaciones en condiciones modernas. Se fundamenta la necesidad de aplicar un enfoque sistemático, se proponen indicadores de seguimiento para determinar los riesgos y diversas amenazas para el funcionamiento y desarrollo de un negocio.

PALABRAS CLAVE: gestión; organización agraria; seguridad económica; integración.

\section{Introduction}

An important aspect of the successful functioning and economic development of agricultural organizations is the internal functional analytical structures of accounting and economic security that register and collect information for further study and corporate business management.

Current competition, generated under modern conditions in Russian market of production and product processing, impacts development and introduction of management accounting into the corporate management system of agricultural companies (Alborov et al., 2017).

Corporate management is a philosophy in modern economic part of all business processes and functioning of a complex for making strategic and important management decisions (Kostyukova and Bobryshev, 2016).

Agricultural company is expected to develop new approaches to improve efficiency of company operation and expand prospects for further development under conditions of some risk in the market (Ivashkevich, 2017). 
REVISTA DE LA UNIVERSIDAD DEL ZULIA. $3^{a}$ época. Año $13 \mathrm{~N}^{\circ}$ 36, 2022

Gamlet Y. Ostaev et al. /// Management accounting and economic safety in corporate ... 158-172 DOI: http://dx.doi.org/10.46925//rdluz.36.11

Economic safety assurance, achieved by establishing analytical centers and decentralization of management system, is an important aspect of successful functioning and economic development of agricultural company and whole business (Molchan, et al., 2020; Frantsisko, et al., 2020).

Management accounting and economic security in the corporate governance of an agricultural company have an important aspect for the functioning of a business.

The problems of management accounting and economic security of an organization are highlighted in many works of economists. Considerable experience has been accumulated in management accounting and economic security of the organization, however, management accounting from the point of view of economic security and corporate governance has its own characteristics, so this methodology requires development.

The aim of the study is to develop a management accounting model in corporate business management, taking into account business development and economic security.

Management accounting in corporate management of a company includes some functions such as business development management (Kontsevoi, et al., 2020).

Management accounting is a method of study and release of data planned by an owner of a business. Distributed by special means and communication channels, this data is intended for definite target users to present and promote business (an idea, final products or services) (Ostaev, et al., 2020).

Being integral part of economic safety system by its very nature, management accounting is an economic framework which gives precise estimation of different indicators influencing business.

Management accounting system comprises data of financial area, tax and management activity, and target, budget and forecast, and conceptualized conditions of business operation. This data takes into account some factors and internal and external threats (Khosiev, et al., 2019).

It should be noted that production cost accounting and output cost determination, being the integral parts of management accounting, combine data fields of financial and management accounting in agricultural company (Ostaev, et al., 2019). Data provision dispatch in rapidly fluctuating internal and external policy and business environment is a 
REVISTA DE LA UNIVERSIDAD DEL ZULIA. $3^{a}$ época. Año $13 \mathrm{~N}^{\circ}$ 36, 2022

Gamlet Y. Ostaev et al. /// Management accounting and economic safety in corporate ... 158-172 DOI: http://dx.doi.org/10.46925//rdluz.36.11

distinctive and principal tool of management accounting in corporate business management (Popper, 2012).

Economic and Management Office and Accounting Office (financial, production and management) as well is expected to make reliable calculation of production cost for the sake of resource saving and providing production process. Being integral part of the corporate management structure, Accounting Office should be clearly differentiated by functions and operational tasks. The structure of accounting department in case of corporate management of agricultural company operation is presented in Table 1.

Table 1 - The structure of accounting department in corporate management of agricultural company operation

\begin{tabular}{|c|lc|l|}
\hline $\begin{array}{c}\text { No } \\
\mathbf{n} / \mathbf{\Pi}\end{array}$ & \multicolumn{1}{|c|}{ Accounting department } & \multicolumn{1}{|c|}{ Management of company operation } \\
\hline 1 & $\begin{array}{l}\text { Financial } \\
\text { Department }\end{array}$ & Accounting & $\begin{array}{l}\text { In case of corporate management of company operation } \\
\text { this department executes observing financial discipline } \\
\text { and sustainable utilization of resources. }\end{array}$ \\
\hline 2 & $\begin{array}{l}\text { Production } \\
\text { Department }\end{array}$ & Accounting & $\begin{array}{l}\text { In case of corporate management of company operation } \\
\text { this department makes cost-information reports on } \\
\text { production (works and services) costs, reveals fund- } \\
\text { drainers and sources of non-manufacturing costs, prepares } \\
\text { loss prevention measures. }\end{array}$ \\
\hline 3 & $\begin{array}{l}\text { Management } \\
\text { department }\end{array}$ & accounting & $\begin{array}{l}\text { In case of corporate management of company operation } \\
\text { researches on business development. Information is } \\
\text { structured by significance in order to make strategic } \\
\text { decisions. }\end{array}$ \\
\hline
\end{tabular}

Compiled by authors

Nowadays management accounting should become the integral information part of well-organized corporate management system of agricultural company operation. Efficiency of management of production operation is provided and supported by information about operation of structural departments and administrative and management departments and offices.

Choice and detailing of cost-accounting objects in corporate management of agricultural company operation is determined by specificities of production process and need and demand in accounting data from the side of business management (Kondratiev, et al., 2020).

Suggested model of management accounting in corporate business management regarding business development and economic safety is presented on Fig. 1. 
REVISTA DE LA UNIVERSIDAD DEL ZULIA. 3a época. Año $13 \mathrm{~N}^{\circ}$ 36, 2022

Gamlet Y. Ostaev et al. /// Management accounting and economic safety in corporate ... 158-172 DOI: http://dx.doi.org/10.46925//rdluz.36.11

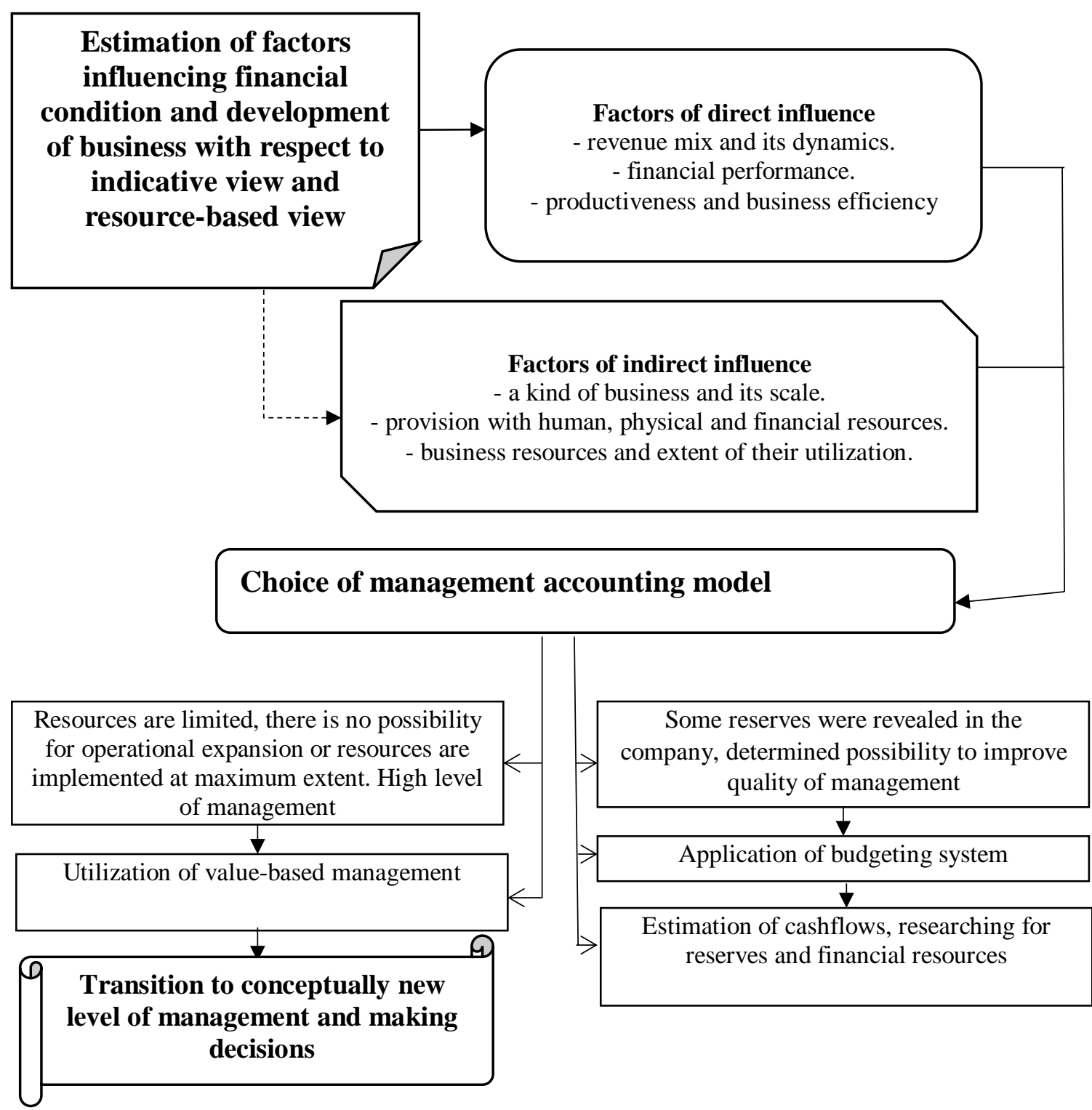

Fig. 1 - Recommended flowchart of determining model of management accounting in corporate business management (developed by the author)

Foremost technical and organizational characteristics of core production influence methodology and arrangement of management accounting in corporate business management. It is caused by the fact that specificity of industry is mostly expressed at the production stage. Hence, arrangement of the efficient information system of corporate business management depends on technical and organizational characteristics of production and processing of raw materials.

The more comprehensive description of busines characteristics and more detailed information, the more efficient decision of management to increase production profitability (Khoruzhy, et al., 2019). 
REVISTA DE LA UNIVERSIDAD DEL ZULIA. $3^{a}$ época. Año $13 \mathrm{~N}^{\circ}$ 36, 2022

Gamlet Y. Ostaev et al. /// Management accounting and economic safety in corporate ... 158-172 DOI: http://dx.doi.org/10.46925//rdluz.36.11

Agricultural and processing companies can achieve targets set earlier in planning of business by means of reliable provision with information, analytical tools and reasonable management decisions. Any taken management decision should be based upon duly analyzed information with respect to economic efficiency, practicability, rate of return and efficiency. In a similar vein, development of a company requires long term outlook estimation of business with respect to management efficiency of company operation.

Considering the role of management accounting in company operation, it should be noted that management accounting is estimated insufficiently in Russia (Mukhina, et al., 2014).

It is caused by the fact that management accounting as a sub-system of bookkeeping accounting appeared quite recently in Russia. However, increasing scale of business, technological improvement and need for improvement of business management under crisis conditions make management accounting more important and cause its extensive use in management system.

\section{Methodology}

The theoretical and methodological basis of the research is the specific application of the theory of scientific knowledge to the subject of research. The research is based on the dialectical method, which determines the study of economic phenomena and processes in interrelation and continuous development. During the research, both general scientific research methods (dialectics, analysis, synthesis, consistency, complexity, analogy, optimization, etc.) and special techniques and procedures (comparison, grouping, generalization, etc.) were used.

The new provisions are substantiated by the results of research and observations obtained by comparative-historical, dialectical-synthetic and abstract-logical methods. The theoretical basis of the research is the works of domestic and foreign scientists on the problems of theory and methodology of management accounting. The methodological basis of the study was formed by the theory of economic development and related theoretical and practical aspects of the methodology and organization of management accounting.

The significance of the study lies in substantiating the nature of the relationship between the effectiveness of the development of management accounting and economic security in the corporate governance of an agricultural organization. 
REVISTA DE LA UNIVERSIDAD DEL ZULIA. $3^{a}$ época. Año $13 \mathrm{~N}^{\circ}$ 36, 2022

Gamlet Y. Ostaev et al. /// Management accounting and economic safety in corporate ... 158-172 DOI: http://dx.doi.org/10.46925//rdluz.36.11

\section{Results and discussion}

Achievement of developmental aims of an object and introduction of these aims into definite business processes are linked with great labor in management accounting and forecasting of condition of a managed object. Reasonable planned model in management accounting is always developed with use of monitoring and forecast data which basically contain analytical results of operation of an economic object over prior periods and other significant internal and external trends. Consequently, the following functions are observed at the initial stage of management process:

- multivariable economic analysis as a set of works in estimation of obtained results (detecting and identification of reserves for further development).

- strategic forecasting as a set of business models of economic actions, which might take place in future.

- adoption of necessary plans and budgets in order to define actions in further economic development of an object.

Management accounting in corporate business management is expected to solve long term outlook problems (Table 2). Development of the model of management accounting in agricultural company assumes that there are some ways of economic future and economic condition is variable one.

Agricultural company should stay capable to keep progressive development and assign its resources to support stable condition under effect of big number of factors of internal and external environment and impact of instability and uncertainty. Hence, management and minimization of risks, appearing during operation activity, should be paid special attention.

In order to define top-priority ways of development, monitoring should be carried out and financial and other indicators of activity should be estimated for budgeting aims as well (Dalkey and Helmer-Hirschberg, 1962).

There are indicators defining quality of budgeting, which characterizes quality of management activity, i.e. statistical and dynamic stability (Rokotyanskaya, et al., 2018).

Statistical stability keeps indicators at the same definite level, and dynamic stability identifies positive changes characterized by development of indicators.

Management decentralization requires arrangement of management accounting by responsibility centers, that helps estimate results and efficiency of activity of each business 
REVISTA DE LA UNIVERSIDAD DEL ZULIA. $3^{a}$ época. Año $13 \mathrm{~N}^{\circ}$ 36, 2022

Gamlet Y. Ostaev et al. /// Management accounting and economic safety in corporate ... 158-172 DOI: http://dx.doi.org/10.46925//rdluz.36.11

segment and its share in total result of operation activity of a company.

Table 2- Management accounting in corporate business management as a guarantee of solving long term outlook problems

\begin{tabular}{|c|c|c|c|}
\hline No. & Parameter & Planned level & Forecasted level \\
\hline 1 & Time slot & $\begin{array}{l}\text { Time period for which a } \\
\text { company has or can make } \\
\text { detailed plans of development } \\
\text { of business }\end{array}$ & $\begin{array}{l}\text { Time period which is } \\
\text { out of detailed plans and } \\
\text { budgets. }\end{array}$ \\
\hline \multicolumn{4}{|c|}{ Nota bene: Distance, space between equally spaced positions is time period } \\
\hline 2 & Risks & $\begin{array}{l}\text { Plans with respect to indicative } \\
\text { specificities do not comprise } \\
\text { big faults and their forming is } \\
\text { not related to unacceptable } \\
\text { costs for business }\end{array}$ & $\begin{array}{l}\text { Formation of plans and } \\
\text { budgets is related to } \\
\text { high extent of } \\
\text { unreliability and/or big } \\
\text { costs. }\end{array}$ \\
\hline \multicolumn{4}{|c|}{ Nota bene: Risk analysis considers internal and external threats. } \\
\hline 3 & Information & $\begin{array}{l}\text { Utmost detailed and reliable } \\
\text { information concerns future } \\
\text { business process in a company. }\end{array}$ & $\begin{array}{l}\text { Information is } \\
\text { generalized and often } \\
\text { has high extent of } \\
\text { uncertainty. }\end{array}$ \\
\hline \multicolumn{4}{|c|}{ Nota bene: Detailed elaboration of information is a primary target. } \\
\hline 4 & Limits & $\begin{array}{l}\text { Opportunity of forming } \\
\text { detailed budget is directed from } \\
\text { business operation plans. }\end{array}$ & $\begin{array}{l}\text { Indicators of business } \\
\text { activity should be } \\
\text { modeled in aggregative } \\
\text { view or they should } \\
\text { have probabilistic } \\
\text { nature. }\end{array}$ \\
\hline
\end{tabular}

Compiled by authors

Arrangement of management accounting by responsibility centers comprises:

- Development of appropriate budgets defining short-term prospects of activity of these centers.

- Arrangement of accounting of costs, incomes and financial results of activity. Responsibility center defines objects of accounting.

- Arrangement of control of planned and descendent facts of business activity of these responsibility centers.

- Formation of internal reporting by responsibility centers in conformance with established system of controlled indicators. 
REVISTA DE LA UNIVERSIDAD DEL ZULIA. $3^{a}$ época. Año $13 \mathrm{~N}^{\circ}$ 36, 2022

Gamlet Y. Ostaev et al. /// Management accounting and economic safety in corporate ... 158-172 DOI: http://dx.doi.org/10.46925//rdluz.36.11

- Analysis of results of activity of responsibility centers and definition of their impact on results of business activity of a company.

Specific conditions of activity of appropriate responsibility centers that is their resource and production capacity, environmental and economic factors of activity, their margin of discretion and responsibility should be considered during development of budgets.

Variation of structure of budget and its expenditure depends on individual, social, economic, environmental, resource and other specificities of a business unit.

Development of budgeting framework defining quality of management of activity is presented on Fig. 2.

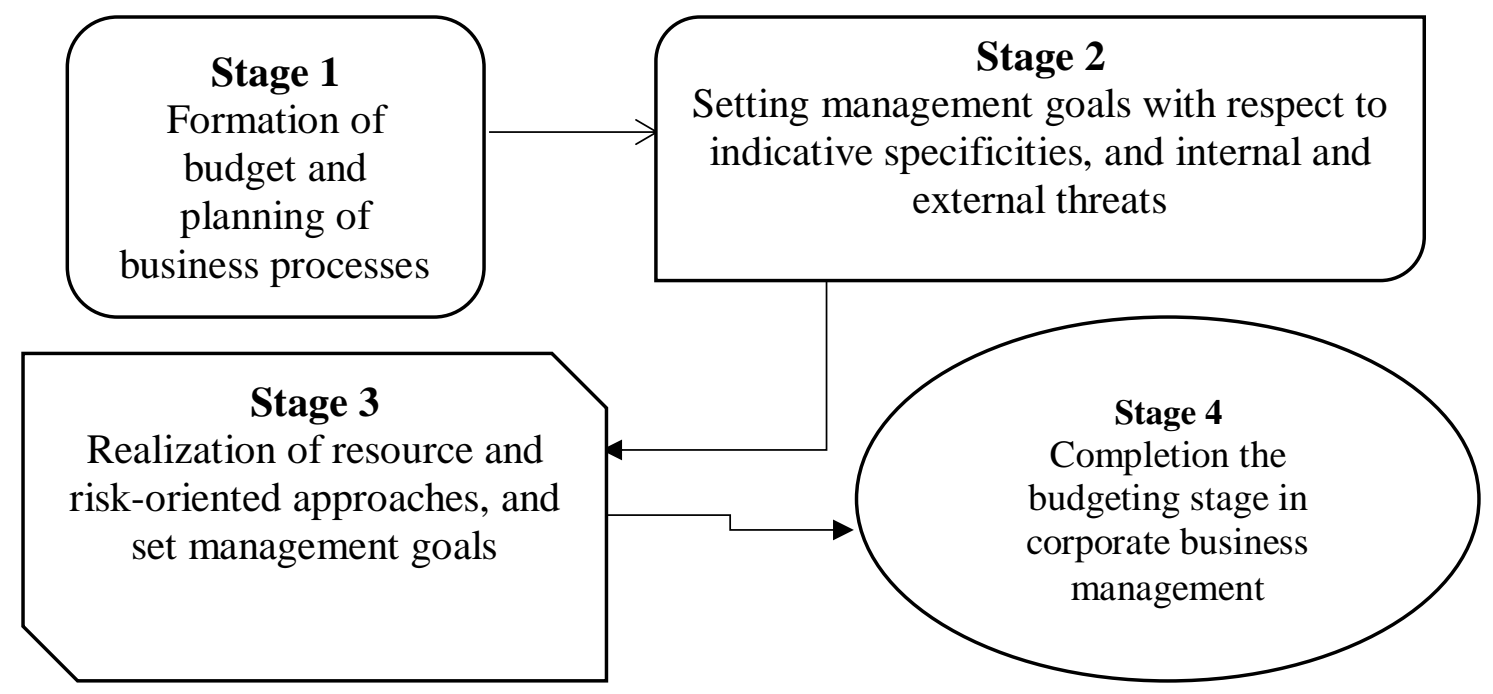

Fig 2 - Flowchart of development of budgeting framework defining quality of management activity (author's development)

Besides, management accounting in corporate business management secures economic safety and it is expressed in protection of interests of agricultural company from appearing threats and providing condition for steady development of a business unit. Reliable and efficient system of economic safety can secure stable social and economic development of a business unit.

Management Accounting Office and Economic Safety Office of a business unit should act as a single entity in the system of monitoring, identification of risks and some threats for operation and development of business.

Being integrated they help define those parameters which should be decided for making reasonable management decisions (Fig.3). 
REVISTA DE LA UNIVERSIDAD DEL ZULIA. 3a época. Año $13 \mathrm{~N}^{\circ}$ 36, 2022

Gamlet Y. Ostaev et al. /// Management accounting and economic safety in corporate ... 158-172

DOI: http://dx.doi.org/10.46925//rdluz.36.11

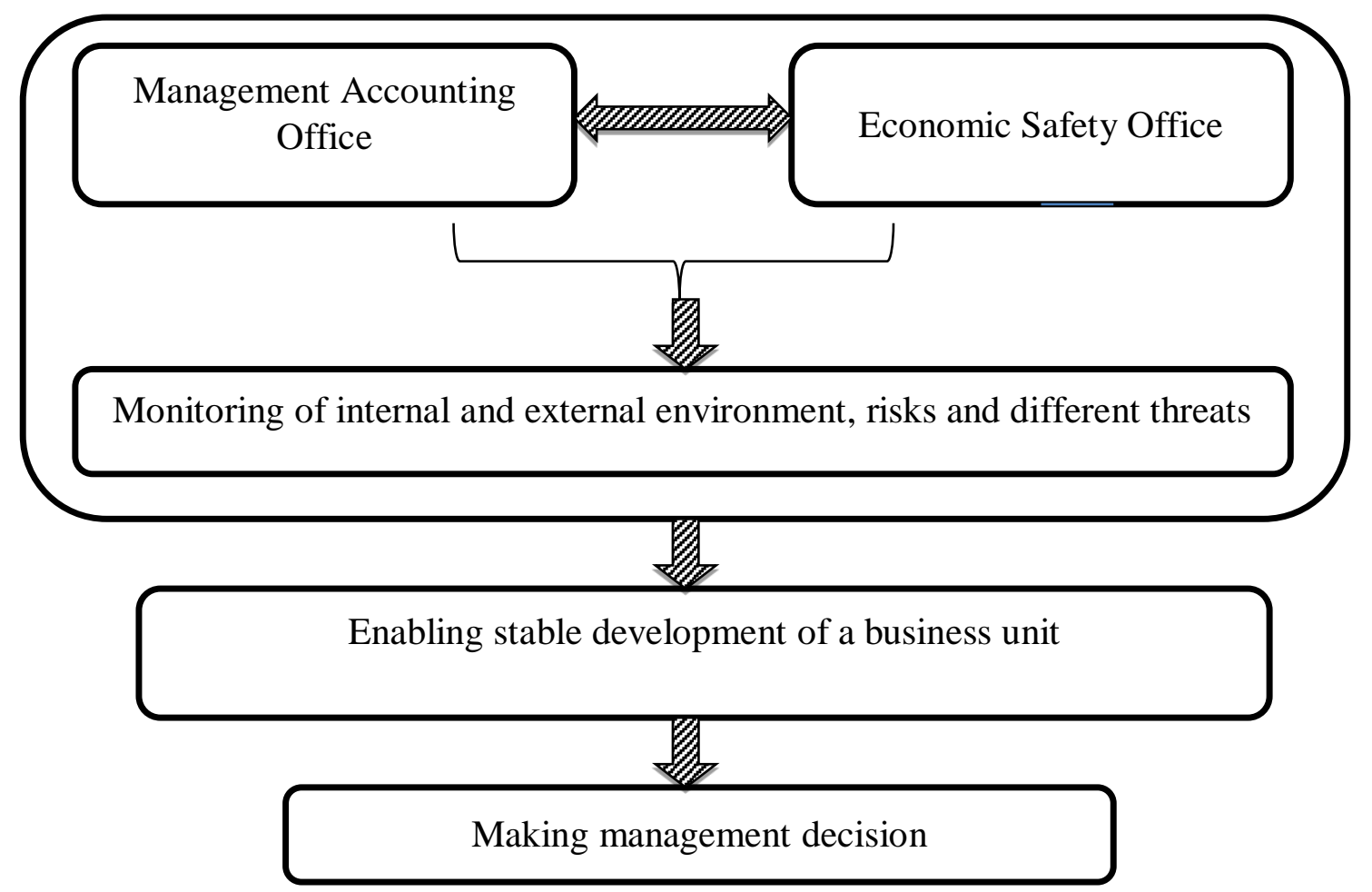

Fig. 3 - Management Accounting Office and Economic Safety Office in the corporate management system of company operation (author's development)

In management accounting some indicators are chosen and subdivided into groups depending on the objects of indicative analysis in order to define criteria of economic safety.

In this research the indicators presented in Table 3 were taken as the universal indicators of economic safety. They define efficiency of agricultural company operation.

A set of indicators used for estimation of economic safety by means of analysis of values of these indicators helps reveal the factors which impact positively and negatively economic safety of a business unit. Consequently, negative impact should be minimized, and positive impact should be strengthened.

The factors of negative impact might cause the following risks for an economic safety system: marketable and material, spatial and time, monetary and cost, intellectual, reference and information, capacity and labor, and special kinds of losses.

The economic safety system in corporate business management is presented on Fig. 4. 


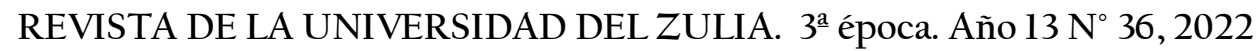

Gamlet Y. Ostaev et al. /// Management accounting and economic safety in corporate ... 158-172 DOI: http://dx.doi.org/10.46925//rdluz.36.11

Table 3 - Indicators for economic safety estimation in agricultural company

\begin{tabular}{|c|c|c|c|c|c|}
\hline \multirow[t]{2}{*}{ Indicator } & \multirow[t]{2}{*}{ Description } & \multicolumn{4}{|c|}{ Quality scoring (indicators) } \\
\hline & & 4 & 3 & 2 & 1 \\
\hline \multicolumn{6}{|c|}{ Indicators of production activity } \\
\hline $\begin{array}{l}\text { Dynamics of } \\
\text { revenue }\end{array}$ & \multirow{2}{*}{$\begin{array}{l}\text { Profitability indicator is the } \\
\text { main one for estimation of a } \\
\text { company. There is direct } \\
\text { dependence of this indicator } \\
\text { and internal control system, the } \\
\text { more efficient operation of } \\
\text { internal control system the } \\
\text { more successfully the main goal } \\
\text { can be achieved. The main goal } \\
\text { of a company is getting profit } \\
\text { and increasing prosperity of } \\
\text { owners. }\end{array}$} & $>100$ & $51-99$ & $10-50$ & $<0$ \\
\hline $\begin{array}{l}\text { Dynamics of sales } \\
\text { profit }\end{array}$ & & $>100$ & $51-99$ & $10-50$ & $<0$ \\
\hline \multicolumn{6}{|c|}{ Indicators of financial condition estimation } \\
\hline $\begin{array}{lll}\text { Total } & \text { Debt } & \text { to } \\
\text { Equity } & & \end{array}$ & $\begin{array}{l}\text { The indicator identifies degree } \\
\text { of financial independence of a } \\
\text { company from the point of } \\
\text { arrangement of total capital. }\end{array}$ & $>0,8$ & $\begin{array}{c}0,5- \\
0,8\end{array}$ & $0,1-0,5$ & $<0$ \\
\hline $\begin{array}{l}\text { Current liquidity } \\
\text { ratio }\end{array}$ & $\begin{array}{l}\text { The indicator identifies the } \\
\text { most of financial solvency of a } \\
\text { company. }\end{array}$ & $>2$ & $1,7-2$ & $1-1,7$ & $<1$ \\
\hline $\begin{array}{l}\text { Degree of solvency } \\
\text { on } \\
\text { liabilities }\end{array}$ & $\begin{array}{l}\text { One of the main indicators used } \\
\text { for estimation of financial } \\
\text { solvency of a company. It helps } \\
\text { define the terms when a } \\
\text { company can pay off current } \\
\text { liabilities under the condition } \\
\text { of saving average monthly } \\
\text { revenue at the level of } \\
\text { accounting period. } \\
\text { Recommended value is Кпто } \leq \\
\text { 3.. }\end{array}$ & $\leq 3$ & $\begin{array}{l}1,1- \\
2,99\end{array}$ & $0,1-1$ & $<0$ \\
\hline \multicolumn{6}{|c|}{ Indicators of efficient utilization of resources, capital and costs } \\
\hline Return on Sales & \multirow{3}{*}{$\begin{array}{l}\text { The indicator gives a } \\
\text { comprehensive view of level of } \\
\text { efficiency of utilization of } \\
\text { company's resources. }\end{array}$} & $>3$ & $1-3$ & $0,1-1$ & $<0$ \\
\hline Return on Assets & & $>3$ & $1-3$ & $0,1-1$ & $<0$ \\
\hline Return on Equity & & $>3$ & $1-3$ & $0,1-1$ & $<0$ \\
\hline $\begin{array}{l}\text { Yield of capital } \\
\text { investments }\end{array}$ & $\begin{array}{l}\text { The indicator identifies level of } \\
\text { efficiency of utilization of basic } \\
\text { production assets of a company. }\end{array}$ & $>5$ & $3-5$ & $1-3$ & $<0$ \\
\hline
\end{tabular}

Compiled by authors 
REVISTA DE LA UNIVERSIDAD DEL ZULIA. $3^{a}$ época. Año $13 \mathrm{~N}^{\circ}$ 36, 2022

Gamlet Y. Ostaev et al. /// Management accounting and economic safety in corporate ... 158-172 DOI: http://dx.doi.org/10.46925//rdluz.36.11

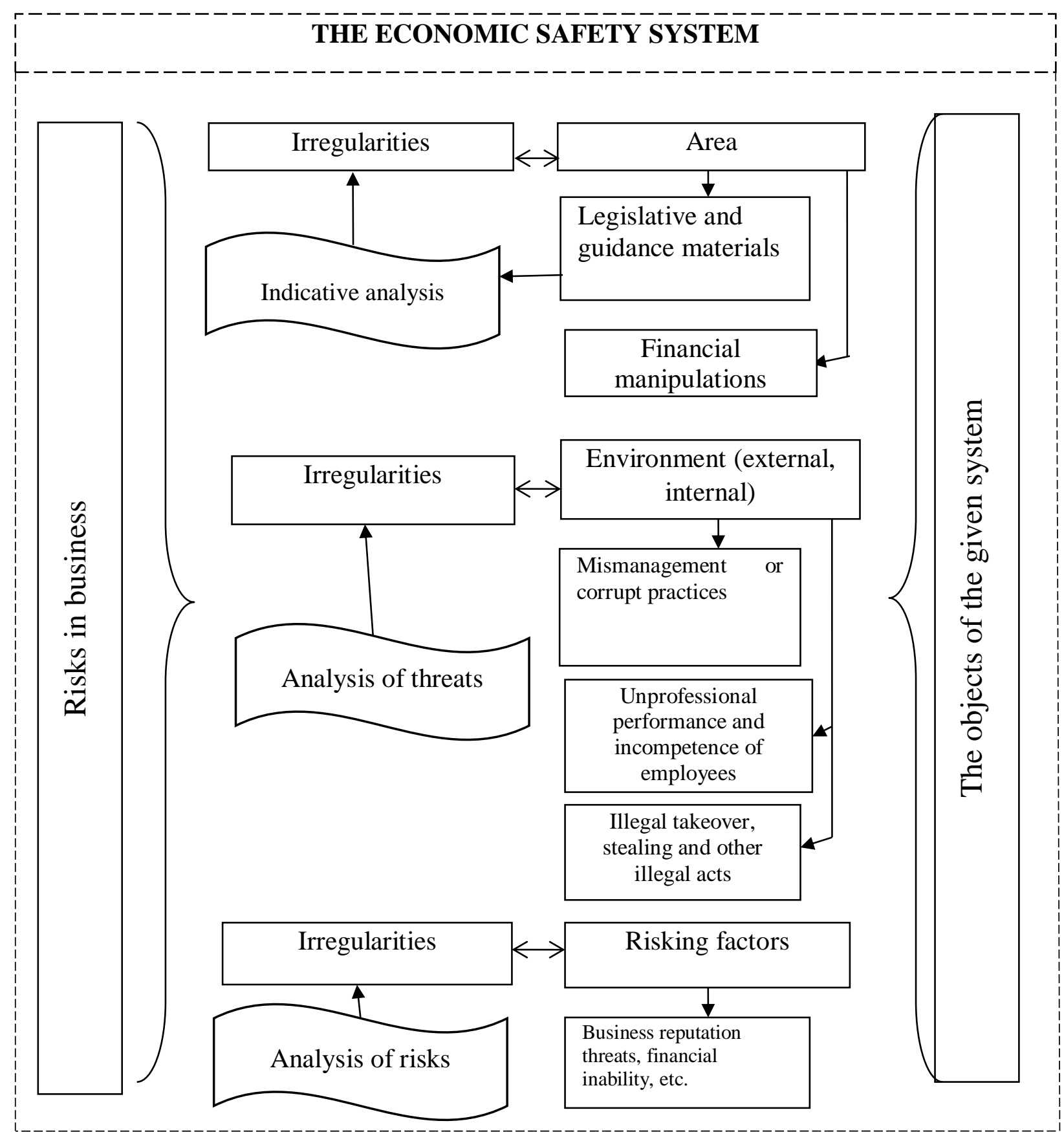

Fig. 4 - The economic safety system in corporate business management (author's development).

Economic safety is provided by Security Office and specialists of Management Accounting Office who perform monitoring of all activity areas of agricultural company.

Management accounting is a such tool of economic safety of business which protects against impact of internal and external derogative factors and provides (reveals) reserves of appropriate resources and management methods.

In order to improve economic safety at business level, management accounting mostly contains aspects of budget formation and distribution of economic resources. Hence, the 
REVISTA DE LA UNIVERSIDAD DEL ZULIA. $3^{a}$ época. Año $13 \mathrm{~N}^{\circ}$ 36, 2022

Gamlet Y. Ostaev et al. /// Management accounting and economic safety in corporate ... 158-172 DOI: http://dx.doi.org/10.46925//rdluz.36.11

matter of costs, control and improvement of fiscal capacity execution should be resolved in management accounting.

Under conditions of digitalization cooperation of management accounting offices in corporate management system of agricultural company is arranged by posting objectives and making tasks within processes and beyond processes with respect to risk management. The task is given to one or more specialists, the terms of performance and the aim of the task is defined, and necessary documents are attached to this task.

The risk management system in agricultural company should be aimed to provide reasonable assurance in performance of the tasks given to a business unit (Table 4).

Table 4 - Targets of risk management in agricultural company

\begin{tabular}{|c|l|l|}
\hline No. & \multicolumn{1}{|c|}{$\begin{array}{c}\text { Target of corporate } \\
\text { management }\end{array}$} & \multicolumn{1}{c|}{ Target area } \\
\hline 1. & Strategic targets & $\begin{array}{l}\text { Providing financial stability and improvement of } \\
\text { financial condition of business }\end{array}$ \\
\hline 2. & Operation targets & $\begin{array}{l}\text { Providing efficiency of financial and operational } \\
\text { activity, resource saving, and preservation of } \\
\text { company's assets. }\end{array}$ \\
\hline 3 & $\begin{array}{l}\text { Targets in reporting } \\
\text { preparation }\end{array}$ & $\begin{array}{l}\text { Providing completeness and reliability of } \\
\text { accounting reports, statistical, management and } \\
\text { other accountings. }\end{array}$ \\
\hline 4 & Targets in law observation & $\begin{array}{l}\text { Observing of applicable legislation and local } \\
\text { regulations }\end{array}$ \\
\hline
\end{tabular}

Compiled by authors

The objectives of the risk management system are development of risk-based corporate culture, improvement of the process of making decisions and choosing the way of response risk in favor of providing economic efficiency of actions on risk management and economic expediency, reduction of unexpected events and losses in operation activity by extending detection of potential events and taking appropriate actions (response risks), and identification and management total risks in operation activity in favor of more efficient responding different impacts with help of integrative approach.

\section{Conclusion}

The results of this research can be used for development theoretical and practical issues of management accounting for the sake of economic safety in any company. So it can 
REVISTA DE LA UNIVERSIDAD DEL ZULIA. $3^{a}$ época. Año $13 \mathrm{~N}^{\circ}$ 36, 2022

Gamlet Y. Ostaev et al. /// Management accounting and economic safety in corporate ... 158-172 DOI: http://dx.doi.org/10.46925//rdluz.36.11

be concluded that companies are expected to collect and process accounting and management information together with accounting and analytical information in order to obtain impartial assessment of internal and external environment in spite of difficulties and specific nature of management accounting for economic safety. Companies should also analyze their operation activity in order to decrease risks. Issues of management accounting and economic safety in corporate management are acute ones and need constant and active research.

\section{References}

Alborov R.A., Kontsevaya S.M., Klychova G.S.and Kuznetsovd V.P. (2017) The development of management and strategic management accounting in agriculture. Journal of Engineering and Applied Sciences. 12(19): 4979-4984. (DOI: 10.3923/jeasci.2017.4979.4984)

Dalkey N.C.and Helmer-Hirschberg O. (1962) An experimental application of the Delphi method to the use of experts. RAND Report RM-727-PR.

Frantsisko, O.Yu., Ternavshchenko, K.O., Molchan, A.S., Ostaev, G.Ya., Ovcharenko, N.A. and Balashova, I.V. (2020) Formation of an integrated system for monitoring the food security of the region. Amazonia Investiga. 9(25): 59-70.

Ivashkevich V.B. (2017) Fundamentals and principles of integrated management accounting. Audit statements. 3:35-44.

Khoruzhy L.I., Gupalova T.N.and Katkov Yu.N. (2019) Integration as a foundation for the establishment of a new model of accounting reporting in agrarian organization. International Journal of Innovative Technology and Exploring Engineering. 6(8): 3064-3070.

Khosiev B.N., Ostaev, G. Ya., Kontsevoy, G. R., Suetin, A. N., Sokolov, V. A., Antonov, P. V. and Suetin, S. N. (2019) Development of a brand promotion strategy: management accounting and comprehensive analysis Indo American Journal of Pharmaceutical Sciences. 6(5): 10060-10068.

Kondratiev D.V., Ostaev G.Ya., Osipov A.K., Bogomolova T.P., Nekrasova E.V.and Abasheva O.V. (2020) Organizational and management mechanism for reforming agricultural organizations based on cooperation and integration of economic systems. Amazonia Investiga. 9(25): 376-388.

Kontsevoi G.R., Ermakov D.N., Rylova N.I., Leoshko V.P.and Safonova M.F. (2020) Management accounting of agricultural production: improving planning and standardization of costs in the management information system. Amazonia Investiga. 9(27): 284-293. (DOI: https://doi.org/10.34069/AI/2020.27.03)

Kostyukova E.I. and Bobryshev A.N. (2016) The concept of information support for the formation and implementation of the business model of an economic entity in the 
REVISTA DE LA UNIVERSIDAD DEL ZULIA. $3^{a}$ época. Año $13 \mathrm{~N}^{\circ}$ 36, 2022

Gamlet Y. Ostaev et al. /// Management accounting and economic safety in corporate ... 158-172 DOI: http://dx.doi.org/10.46925//rdluz.36.11

management accounting system, pp. 99-105. History, state and prospects for the development of agroeconomic science and education Materials of the International Scientific and Practical Conference.

Molchan A.S., Frantsisko O.Yu., Ternavshchenko K.O., Ostaev G.Ya., Tinyakova V. I.and Markovina E. V.(2020) Optimization of interaction of agrarian entities as an imperative of ensuring food security of the state. Amazonia Investiga. 9(26): 242-253. (DOI: https://doi.org/10.34069/AI/2020.26.02)

Mukhina I.A., Markovina N.V. and Pimenova N.B. (2014) Methodological issues of applying qualimetry methods in assessing the quality of state and municipal management. Law and State: Theory and Practice. 3(111): 12-18.

Ostaev G.Ya., Gogolev, I.M., Kondratev, D.V., Markovina, E.V., Mironova, M.V., Kravchenko N.A. and Alexandrova, E.V. (2019) Strategic budgeting in the accounting and management system of agricultural enterprises. Indo American Journal of Pharmaceutical Sciences. 6(04): 8180-8186.

Ostaev G.Ya., Shulus A. A.,Mironova M. V.and Smolin E.V.(2020) Accounting agricultural business from scratch: management accounting, decision making, analysis and monitoring of business processes. Amazonia Investiga. 9(27): 319 -332. (DOI: https://doi.org/10.34069/AI/2020.27.03)

Popper R. (2012) Monitoring Future Research. Foresight. 6(2): 56-74.

Rokotyanskaya V.V., Moshchenko O.V., Valuiskov N.V., Ostaev G.Y.and, Taranova N.S. (2018) Control and analytical management aspects of debtor and credit deposit of enterprises. Journal of Applied Economic Sciences, vol. 13(2): 446-453. 